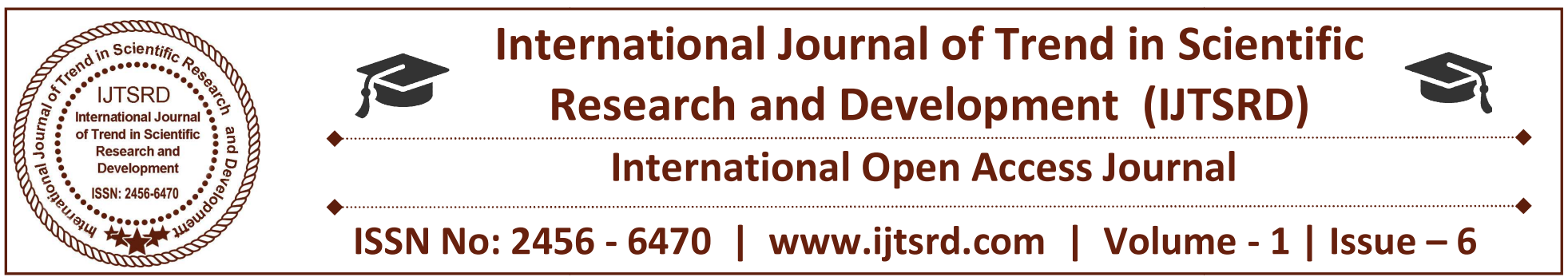

\title{
Innovative Technologies for Minimizing Waste Water
}

\author{
Nazakat Ali \\ Department of Biotechnology, \\ Lovely Professional University, Phagwara, Punjab, India
}

\section{ABSTRACT}

Important challenges in the global water situation, mainly resulting from worldwide population growth and climate change, require novel innovative water technologies in order to ensure a supply of drinking water and reduce global water pollution. Against this background, the adaptation of highly advanced nanotechnology to traditional process engineering offers new opportunities in technological developments for advanced water and wastewater technology processes. Here, an overview of recent advances in nanotechnologies for water and wastewater treatment processes is provided, including nanobased materials, such as nanoadsorbents, nanometals, nanomembranes, and photocatalysts. The beneficial properties of these materials as well as technical barriers when compared with conventional processes are reported. The state of commercialization is presented and an outlook on further research opportunities is given for each type of nanobased material and process. In addition to the promising technological enhancements, the limitations of nanotechnology for water applications, such as laws and regulations as well as potential health risks, are summarized. The legal framework according to nanoengineered materials and processes that are used for water and wastewater treatment is considered for European countries and for the USA.

Keywords: nanotechnology, water technology, nanoadsorbents, nanometals, nanomembranes, photocatalysis

\section{INTRODUCTION}

The long-term development of the global water situation is closely connected to the growth of the world population and global climate change. Constant growth of the world's population, which is forecasted to be nearly doubled from 3.4 billion in 2009 to 6.3 billion people in 2050, is attended by a predicted needed growth of agriculture production of $70 \%$, by 2050.Thus, the demand for fresh water is growing dramatically, in particular for food production, since $70 \%$ of the world's freshwater withdrawals are already accounted for by agricultural irrigation. Currently, 64 billion cubic meters of fresh water are progressively consumed each year.

The arid regions of North Africa and nearly half of the European countries (approximately $70 \%$ of the population) are confronted with a lack of water supply. Even industrialized countries like the USA, providing highly innovative technologies for saving and purifying water, show the difficulty of exhausted water reservoirs due to the fact that more water is extracted than refilled. In the People's Republic of China, 550 of the 600 largest cities suffer from a water shortage, since the biggest rivers are immensely polluted and even their use for irrigation has to be omitted, not to mention treatment for potable water.

A group of leading climate impact researchers have shown that climate change possibly exacerbates the regional and global water scarcity. They predict that global warming of $2{ }^{\circ} \mathrm{C}$ above present temperatures will confront an additional approximately $15 \%$ of the global population with a severe decrease in water resources and will increase the number of people living under absolute water scarcity $(<500 \mathrm{~m} 3$ per 
capita per year) by at least another $40 \%$ compared with the effect of population growth alone.

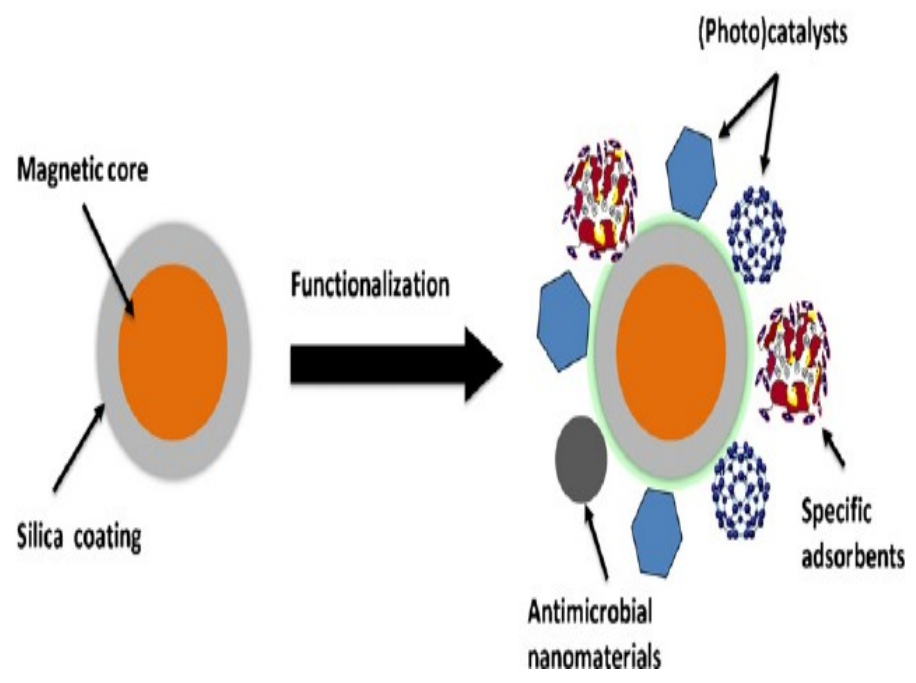

The USA has faced the most terrible drought for the last 50 years. In contrast, in rainy countries, heavy rainfall can lead to erosion and soil run-off, which is why pathogens enter water bodies along with soil components and nutrients. Increased temperatures in air and raw water can affect the drinking water hygiene in respective storage systems as well as in drinking water pipelines, resulting in harmful infectious illnesses. For example, Legionnaire's disease might occur, caused by legionella bacteria that reach a population maximum in warm water of around $40^{\circ} \mathrm{C}$.

In both developing and industrialized countries, a growing number of contaminants like micropollutants are entering the water bodies. Conventional decontamination processes such as chlorination and ozonation consume a high amount of chemical agents and, furthermore, can produce toxic byproducts.

The adaptation of highly advanced nanotechnology to traditional process engineering offers new opportunities for development of advanced water and wastewater technology processes. Here, an overview of recent advances in nanotechnologies for water and wastewater processes is provided, including nanobased materials, processes, and their applications. Besides the promising technological enhancements, the limitations of nanotechnology for water applications, such as laws and regulations as well as potential health risks, are reported.
Processes and applications nanomaterials

Dependent properties related to their high specific surface area (fast dissolution, high reactivity, strong sorption) and discontinuous properties (such as superparamagnetism, localized surface plasmon resonance, and quantum confinement effect). These specific nanobased characteristics allow the development of novel high-tech materials for more efficient water and wastewater treatment processes, namely membranes, adsorption materials, nanocatalysts, functionalized surfaces, coatings, and reagents. The most promising materials and applications are highlighted in Table 1.

\section{Table 1}

Overview of types of nano materials applied for water and wastewater technologies

\begin{tabular}{lll}
\hline Nanomaterial & Properties & Applications \\
\hline Nanoadsorbents & $\begin{array}{l}\text { + high specific surface, higher adsorption } \\
\text { rates, small footprint } \\
\text { - high production costs }\end{array}$ & $\begin{array}{l}\text { Point-of-use, removal of i } \\
\text { bacteria }\end{array}$ \\
$\begin{array}{l}\text { Nanometals and } \\
\text { nanometal oxides }\end{array}$ & $\begin{array}{l}\text { compressible, abrasion-resistant, magnetic } \\
\text { + photocatalytic }\left(\mathrm{WO}_{3}, \mathrm{TiO}_{2}\right)\end{array}$ & $\begin{array}{l}\text { Removal of heavy metals } \\
\text { media filters, slurry reactor }\end{array}$ \\
& - less reusable & \\
Membranes and & + reliable, largely automated process & All fields of water and was \\
membrane & - relative high energy demand & \\
processes & & \\
\hline
\end{tabular}

\section{POTENTIAL ECOTOXICITY OF NANOBASED MATERIALS AND PROCESSES RELATED TO WATER APPLICATIONS}

Nanomaterials in water do not directly affect humans, but there is the possibility of uptake of nanomaterials via consumption of fish, so the impact of nanomaterials on aquatic organisms needs to be taken into consideration. The harmful effects of nanomaterials on aquatic organisms are related mainly to nanoparticles, so the following section is concerned with the potential toxicity of $\mathrm{TiO} 2$ nanoparticles, 67 silver nanoparticles, 68 and CNTs,69,70 which are the most common nanoparticle species. 
International Journal of Trend in Scientific Research and Development (IJTSRD) ISSN: 2456-6470

Current research activities mainly focus on the following types of nanoadsorbents:

\section{carbon-based nanoadsorbents ie, carbon nanotubes (CNTs)}

\section{metal-based nanoadsorbents}

\section{polymeric nanoadsorbents}

\section{zeolites.}

Carbon nanotubes CNTs are allotropes of carbon with a cylindrical nanostructure. Depending on their manufacturing process, CNTs are categorized as single-walled nanotubes and multiwalled nanotubes, respectively. Besides having a high specific surface area, CNTs possess highly assessable adsorption sites and an adjustable surface chemistry. Due to their hydrophobic surface, CNTs have to be stabilized in aqueous suspension in order to avoid aggregation that reduces the active surface. They can be used for adsorption of persistent contaminants as well as to preconcentrate and detect contaminants. Metal ions are adsorbable by CNTs through electrostatic attraction and chemical bonding.

\section{$>$ Carbon nanotubes}

CNTs are allotropes of carbon with a cylindrical nanostructure. Depending on their manufacturing process, CNTs are categorized as single-walled nanotubes and multiwalled nanotubes, respectively. Besides having a high specific surface area, CNTs possess highly assessable adsorption sites and an adjustable surface chemistry. Due to their hydrophobic surface, CNTs have to be stabilized in aqueous suspension in order to avoid aggregation that reduces the active surface. They can be used for adsorption of persistent contaminants as well as to preconcentrate and detect contaminants. Metal ions are adsorbable by CNTs through electrostatic attraction and chemical bonding.

Furthermore, CNTs exhibit antimicrobial properties by causing oxidative stress in bacteria and destroying the cell membranes. Although chemical oxidation occurs, no toxic byproducts are produced, which is an important advantage over conventional disinfection processes like chlorination and ozonation. They can be simply regenerated through appropriate adjustments of operating conditions, like $\mathrm{pH}$ shift.

Conventional desalination methods are energyconsuming and technically demanding, whereas adsorption-based techniques are simple and easy to use for point-of-use water purification devices, yet their capacity to remove salts is limited. Yan et al developed plasma-modified ultralong CNTs that feature an ultrahigh specific adsorption capacity for salt (exceeding $400 \%$ by weight) that is two orders of magnitude higher when compared with conventional carbon-based water treatment systems. These ultralong CNTs can be implemented in multifunctional membranes that are able to remove not only salt but also organic and metal contaminants. Next-generation potable water purification devices equipped with these novel CNTs are expected to have superior desalination, disinfection, and filtration properties.

\section{Polymeric nanoadsorbents}

Polymeric nanoadsorbents such as dendrimers (repetitively branched molecules) are utilizable for removing organics and heavy metals. Organic compounds can be adsorbed by the interior hydrophobic shells, whereas heavy metals can be adsorbed by the tailored exterior branches. Diallo et al integrated dendrimers in an ultrafiltration device in order to remove copper from water. Nearly all copper ions were recovered by use of this combined dendrimer-ultrafiltration system. The adsorbent is regenerated simply through a $\mathrm{pH}$ shift. However, due to the complex multistage synthesis of dendrimers, up until now there are no commercial suppliers, except for some recently founded companies in the People's Republic of China.

Sadeghi-Kiakhani et al produced a highly efficient bioadsorbent for the removal of anionic compounds such as dye from textile wastewater by preparing a combined chitosan-dendrimer nanostructure. The bioadsorbent is biodegradable, biocompatible, and nontoxic. They achieve removal rates of certain dyes up to $99 \%$.

\section{$>$ Zeolites}

Zeolites in combination with silver atoms have been known since the early 1980s. Zeolite has a very porous structure in which nanoparticles such as silver 
ions can be embedded. There they are released from the zeolite matrix by exchange with other cations in solution. Egger et al compared various materials containing nanosilver, including zeolites. When used for sanitary purposes, the silver attacks microbes and inhibits their growth, as shown by Agion ${ }^{\circledR}$ (Sciessent LLC, Wakefield, MA, USA).

A small amount of silver ions is released from the metallic surface when placed in contact with liquids. The success of this composition in water disinfection was shown once again by Petrik et al. The Water Research Commission Report No KV 297/12 shows the innovative use of zeolites as an adsorbing platform for silver nanoparticles as a source of silver ions for a disinfectant. Another possibility is applying zeolites themselves as nanoparticles, as shown by Tiwari et al, who prepared nanozeolites by laser-induced fragmentation of zeolite Linde type A microparticles and Jung et al, who used nanozeolites in sequencing batch reactors for waste water treatment.

For example, the Agion product line includes a compound made from zeolites and naturally occurring silver ions that exhibits antibacterial properties.

Table 2 summarizes the most important properties, applications, and innovative approaches of nanoadsorbents.

\section{Table 2}

Properties, applications, and innovative approaches of nanoadsorbents

Nanoads orbents Properties

Positive

Carbon

nanotubes sides, bactericidal, reusable

risk

Negative

High production

sts, possibly health degradable

isk

contaminants

(pharmaceuticals,

antibiotics)

Polymeric

nanoadsorbents

(dendrimers)

Bifunctional (inner shell

adsorbs organics, outer

branches adsorb heavy

metals), reusable

Zeolites
Controlled release of

\section{Complex multistage}

production process

Removal of organics

and heavy metals

\section{CONCLUSION AND FUTURE PROSPECTS}

There is a significant need for novel advanced water technologies, in particular to ensure a high quality of drinking water, eliminate micropollutants, and intensify industrial production processes by the use of flexibly adjustable water treatment systems. Nanoengineered materials, such as nanoadsorbents, nanometals, nanomembranes, and photocatalysts, offer the potential for novel water technologies that can be easily adapted to customer-specific applications. Most of them are compatible with existing treatment technologies and can be integrated simply in conventional modules. One of the most important advantages of nanomaterials when compared with conventional water technologies is their ability to integrate various properties, resulting in multifunctional systems such as nanocomposite membranes that enable both particle retention and elimination of contaminants. Further, nanomaterials enable higher process efficiency due to their unique characteristics, such as a high reaction rate. 
However, there are still several drawbacks that have to be negotiated. Materials functionalized with nanoparticles incorporated or deposited on their surface have risk potential, since nanoparticles might release and emit to the environment where they can accumulate for long periods of time. Up until now, no online monitoring systems exist that provide reliable real-time measurement data on the quality and quantity of nanoparticles present only in trace amounts in water, thus offering a high innovation potential. In order to minimize the health risk, several national and international regulations and laws are in preparation. Another more technical limitation of nanoengineered water technologies is that they are rarely adaptable to mass processes, and at present, in many cases are not competitive with conventional treatment technologies. Nevertheless, nanoengineered materials offer great potential for water innovations in the coming decades, in particular for decentralized treatment systems, point-of-use devices, and heavily degradable contaminants.

\section{REFERENCES}

1) Hyung H, Kim JH. Dispersion of C60 in natural water and removal by conventional drinking water processes. Water Res. 2009;43:2463-2470.

2) Baun A, Sørensen SN, Rasmussen RF, Hartmann NB, Koch CB. Toxicity and bioaccumulation of xenobiotic organic compounds in the presence of aqueous suspensions of nano-C60. Aquat Toxicol. 2008;86:379-387.

3) Warheit DB, Hoke RA, Finlay C, Donner EM, Reed KL, Sayes CM. Development of a base set of toxicity tests using ultrafine $\mathrm{TiO} 2$ particles as a component of nanoparticle risk management. Toxicol Lett. 2007;171:99-110.

4) Jackson P, Jacobsen NR, Baun A, et al. Bioaccumulation and ecotoxicity of carbon nanotubes. Chem Cent J. 2013;7:154.

5) Horizon 2020 Work Programme 2014-2015. 5. Leadership in enabling and industrial technologies. II. Nanotechnologies,Advanced Materials, Biotechnology and Advanced Manufacturing and Processing. [Accessed July 24, 2014].

6) Kim ES, Hwang G, El-Din MG, Liu Y. Development of nanosilver and multi-walled carbon nanotubes thin-film nanocomposite membrane for enhanced water treatment. J Memb Sci. 2012;394:37-48.
7) Cong Q, Yuan X, Qu J. A review on the removal of antibiotics by carbon nanotubes. Water Sci Technol. 2013;68:S1679-S1687.

8) Qu X, Alvarez PJ, Li Q. Applications of nanotechnology in water and wastewater treatment. Water Res. 2013;47:3931-3946.

9) Hajeh M, Laurent S, Dastafkan K. Nanoadsorbents: classification, preparation, and applications (with emphasis on aqueous media) Chem Rev. 2013;113:S7728-S7768.

10) Diallo MS, Christie S, Swaminathan P, Johnson JH, Goddard WA. Dendrimer enhanced ultrafiltration. 1. Recovery of $\mathrm{Cu}(\mathrm{II})$ from aqueous solutions using PAMAM dendrimers with ethylenediamine core and terminal $\mathrm{NH} 2$ groups. Environ Sci Technol. 2005;39:S1366-S1377.

11) Sadeghi-Kiakhani M, Mokhtar Arami M, Gharanjig K. Dye removal from colored-textile wastewater using chitosan-PPI dendrimer hybrid as a biopolymer: optimization, kinetic, and isotherm studies. J Appl Polym Sci. 2013;127:2607-2619.

12) Baker MD, Ozin GA, Godber J. Far-infrared studies of silver atoms, silver ions, and silver clusters in zeolites A and Y. J Phys Chem. 1985;89:305-311.

13) Egger S, Lehmann RP, Height MJ, Loessner MJ, Schuppler M. Antimicrobial properties of a novel silver-silica nanocomposite material. Appl Environ Microbiol. 2009;75:2973-2976.

14) Nagy A, Harrison A, Sabbani S, Munson RS, Jr, Dutta PK, Waldman WJ. Silver nanoparticles embedded in zeolite membranes: release of silver ions and mechanism of antibacterial action. Int $\mathrm{J}$ Nanomedicine. 2011;6:1833-1852.

15) Petrik L, Missengue R, Fatoba M, Tuffin M, Sachs J. Silver/zeolite nano composite-based clay filters for water disinfection. Report to the Water Research Commission. No KV 297/12.

16) Tiwari DK, Behari J, Sen P. Application of nanoparticles in waste water treatment. World Applied Sciences Journal. 2008;3:417-433.

17) Jung JY, Chung YC, Shin HS, Son DH. Enhanced ammonia nitrogen removal using consistent biological regeneration and ammoniumexchange of zeolite in modified SBR process. Water Res. 2004;38:347-354.

18) Aredes S, Klein B, Pawlik M. The removal of arsenic from water using natural iron oxide minerals. Journal of Cleaner Production. 2012;2930:208-213. 
International Journal of Trend in Scientific Research and Development (IJTSRD) ISSN: 2456-6470

19) Feng $C$, Khulbe $\mathrm{KC}$, Matsuura $\mathrm{T}$, Tabe $\mathrm{S}$, Ismail AF. Preparation and characterization of electrospun nanofiber membranes and their possible applications in water treatment. Separation and Purification Technology. 2013;102:118-135.

20) Kim ES, Deng B. Fabrication of polyamide thinfilm nano-composite (PA-TFN) membrane with hydrophilized ordered mesoporous carbon $(\mathrm{H}-$ OMC) for water purifications. J Memb Sci. 2011;375:46-54.

21) Fathizadeh M, Aroujalian A, Raisi A. Effect of added NaXnano-zeolite into polyamide as a top thin layer of membrane on water flux and salt rejection in a reverse osmosis process. J Memb Sci. 2011;375:88-95.

22) Gehrke I, Keuter V, Groß F. Development of nanocomposite membranes with photocatalytic surfaces.J Nanosci Nanotechnol. 2012;12:91639168.

23) Gehrke I. Environmental friendly recycling of strategic metals. Fraunhofer UMSICHT Annual Report. 2013.

24) Whitesides GM, Grzybowski B. Self-assembly at all scales. Science. 2002;295:2418-2421.

25) Qiu X, Yu H, Karunakaran M, Pradeep N, Nunes SP, Peinemann KV. Selective separation of similarly sized proteins with tunable nanoporous block copolymer membranes. ACS Nano. 2013;7:768-776.

26) Pendergast MT, Dorin RM, Phillip WA, Wiesner U, Hoek EM. Understanding the structure and performance of self-assembled triblock terpolymer membranes. J Memb Sci. 2013;444:461-468.

27) Cloete TE, de Kwaadsteniet M, Botes M, LopezRomero JM. Nanotechnology in Water Treatment Applications. Norfolk, UK: Caister Academic Press; 2010.

28) Ramakrishna S, Fujihara K, Teo WE, Yong T, Ma ZW, Ramaseshan R. Electrospun nanofibers: solving global issues. Mater Today. 2006;9:40-50.

29) Karim MR, Rhodes ER, Brinkman N, Wymer L, Shay Fout G. New electropositive filter for concentrating enteroviruses and noroviruses from large volumes of water. Appl Environ Microbiol. 2009;75:2393-2399.

30) Tang CY, Zhao Y, Wang R, Hélix-Nielsen C, Fane AG. Desalination by biomimetic aquaporin membranes: review of status and prospects. Desalination. 2013;308:34-40.

31) Xie W, He F, Wang B, et al. An aquaporin-based vesicle-embedded polymeric membrane for low energy water filtration. J Mater Chem A. 2013;1:7592-7600.

32) Espinoza LA. Band 51, Schriftenreihe des Lehrstuhls für Wasserchemie und der DVGWForschungsstelle am Engler-Bunte-Institut des Karlsruher Instituts für Technologie (KIT) Karlsruhe: 2010. Heterogeneous photocatalysis with titanium dioxide suspensions containing bromide and dissolved organic carbon. (DVGWseries, Karlsruher Institute of Technology). German.

33) Friedmann D, Mendiveb C, Bahnemann D. TiO2 for water treatment: parameters affecting the kinetics and mechanisms of photocatalysis. Appl Catal B Environ. 2010;99:398-406.

34) Chong MN, Jin B, Chow CW, Saint C. Recent developments in photocatalytic water treatment technology: a review. Water Res. 2010;44:29973027.

35) Fujishima A, Zhang $X$, Tryk DA. TiO2 photocatalysis and related surface phenomena. Surf Sci Rep. 2008;63:515-582.

36) Gaya UI, Abdullah AH. Heterogeneous photocatalytic degradation of organic contaminants over titanium dioxide: a review of funda mentals, process and problems. J Photochem Photobiol A Chem. 2008;9:1-12.

37) Meng ZD, Zhu L, Ye S, et al. Fullerene modification $\mathrm{CdSe} / \mathrm{TiO} 2$ and modification of photocatalytic activity under visible light. Nanoscale Res Lett. 2013;8:189-199.

38) Meng ZD, Zhu L, Choi JC, Park CY, Oh WC. Preparation, characterization and photocatalytic behavior of WO3-fullerene/TiO2 catalysts under visible light. Nanoscale Res Lett. 2011;6:459.

39) Lazar MA, Varghese S, Nair SS. Photocatalytic water treatment by titanium dioxide: recent updates. Catalysts. 2012;2:572-601.

40) Sukhanova, A., Devy, M., Venteo, L., Kaplan, H., Artemyev, M.,Oleinikov, V., Klinov, D., Pluot, M., Cohen, J.H.M., Nabiev, I.,2004. Biocompatible fluorescent nanocrystals for immunolabeling of membrane proteins andcells. Analytical Biochemistry 324 (1), 60e67.

41) Sylvester, P., Westerhoff, P., Mooller, T., Badruzzaman, M.,Boyd, O., 2007. A hybrid sorbent utilizing nanoparticles of hydrous iron oxide for arsenic removal from drinking water.Environmental Engineering Science 24 (1), $104 \mathrm{e} 112$. 
International Journal of Trend in Scientific Research and Development (IJTSRD) ISSN: 2456-6470

42) Theron, J., Cloete, T.E., de Kwaadsteniet, M., 2010. Current molecular and emerging nanobiotechnology approaches for the detection of microbial pathogens. Critical Reviews in Microbiology 36 (4), 318e339.

43) Tiede, K., Boxall, A.B.A., Tear, S.P., Lewis, J., David, H.,Hassellov, M., 2008. Detection and characterization of engineered nanoparticles in food and the environment. Food Additives and Contaminants 25 (7), 795e821.

44) Tiraferri, A., Vecitis, C.D., Elimelech, M., 2011. Covalent binding of single-walled carbon nanotubes to polyamide membranes for antimicrobial surface properties. Acs Applied Materials \& Interfaces 3 (8), 2869e2877.

45) Trivedi, P., Axe, L., 2000. Modeling Cd and Zn sorption to hydrous metal oxides. Environmental Science and Technology 34 (11),2215e2223.

46) Vecitis, C.D., Schnoor, M.H., Rahaman, M.S.,h Schiffman, J.D.,Elimelech, M., 2011. Electrochemical multiwalled carbon nanotube filter for viral and bacterial removal and inactivation. Environmental Science and Technology 45 (8), 3672e3679.

47) Vecitis, C.D., Zodrow, K.R., Kang, S., Elimelech, M., 2010.Electronic-structure-dependent bacterial cytotoxicity of single-walled carbon nanotubes. Acs Nano 4 (9), 5471e5479.

48) Vikesland, P.J., Wigginton, K.R., 2010. Nanomaterial enabled biosensors for pathogen monitoring e a review.Environmental Science and Technology 44 (10), 3656e3669.

49) Westerhoff, P., De Haan, M., Martindale, A., Badruzzaman, M.,2006. Arsenic adsorptive media technology selection strategies. Water Quality Research Journal of Canada 41 (2),171e184.

50) Westerhoff, P., Moon, H., Minakata, D., Crittenden, J., 2009. Oxidation of organics in retentates from reverse osmosis wastewater reuse facilities. Water Research 43 (16), 3992e3998.

51)WHO, 2012. Progress on Drinking Water and Sanitation. 2012 Update.Wu, L., Shamsuzzoha, M., Ritchie, S.M.C., 2005. Preparation of cellulose acetate supported zero-valent iron nanoparticles for

the dechlorination of trichloroethylene in water. Journal of Nanoparticle Research 7 (4e5), $469 \mathrm{e} 476$.

52) Wu, L.F., Ritchie, S.M.C., 2008. Enhanced dechlorination of trichloroethylene by membranesupported Pd-coated iron nanoparticles. Environmental Progress 27 (2), $218 \mathrm{e} 224$. 